\title{
Effect of Different Processing Parameters on Quality Factors and Image Texture Features of Bread
}

Mahdi Karimi ${ }^{1}$, Milad Fathi ${ }^{1,2 *}$, Zahra Sheykholeslam ${ }^{1}$, Bahareh Sahraiyan ${ }^{3}$ and Fariba Naghipoor ${ }^{3}$

${ }^{1}$ Khorasan Razavi Agricultural and Natural Resources Research Center, Iran

${ }^{2}$ Department of Food Science and Technology, Isfahan University of Technology (IUT), Isfahan, 84156-83111, Iran

${ }^{3}$ Department of Food Science and Technology, Ferdowsi University of Mashhad (FUM), Mashhad, Iran

\begin{abstract}
In this research, image texture analysis as a nondestructive and rapid method was applied for estimation of mechanical texture property of bread. Bread samples were formulated using different emulsifiers (i.e. SSL, DATEM and E471) in three concentrations $(0.2,0.4$ and $0.6 \%)$ at three proofing times $(25,35$ and $45 \mathrm{~min})$ and sensory properties, specific volume, color components (i.e. $L^{*}, a^{*}$ and $b^{*}$ ), porosity, hardness and four image texture features (i.e. contrast, correlation, energy and homogeneity) were determined. The results indicated that emulsifier treated samples showed better $(p<0.05)$ sensory perceptions in compression to control samples. However, the proofing time did not show significant effect. Application of E471 significantly increased the specific volume of bread. Emulsifier treated samples had higher lightness values. Application of higher concentration and longer proofing time led to higher porosity of bread. Emulsifiers, their concentrations and proofing times had positive significant $(p<0.05)$ effects on softness of bread. On the other side of this research, contrast, correlation, energy and homogeneity were calculated from Grey Level CoOccurrence Matrix (GLCM). They showed splendid correlations with hardness of bread $(0.958,0.973,0.966$ and 0.91 , respectively). Multiple Linear Regression (MLR) was conducted between hardness and four image texture features and the mathematical equation could predict hardness with high correlation of coefficient of 0.994 . These results strongly suggest that image texture analysis can be applied as a nondestructive and rapid method for estimation of hardness of bread.
\end{abstract}

Keywords: Bread; Image Texture Analysis; Mechanical Texture Property; Emulsifier; Proofing Time

\section{Introduction}

Bread is one of the oldest and most popular diets all over the world. Consumer demand is toward consumption of high quality fresh bread. However, this product has a short shelf life. Therefore, application of some additives (e.g. emulsifiers) and process modifications are necessary to overcome this limitation and improve other quality parameters of bread such as sensory and rheological features. The main mechanism by which the emulsifiers retard the firming or retrogradating of crumb is based on their capability to form inclusion complexes with amylose part of starch during the baking process [1-2]. Several studies have been carried out to show the potential application of emulsifiers in the bakery products [3-5]. On the other hand, proofing time is also one of the important processing parameters affecting final quality of bread due to production of gas bubbles [6].

Mechanical texture features are recognized as one of the most important quality aspects affecting sensory perception and shelf life of bread. However, determination of these physical properties using physical instruments are both time consuming and destructive. Image textures are important image features and have been recently applied in food sector for quality evaluation as a nondestructive, objective and rapid method [7-11]. Published data revealed that image texture features can be used for determination of mechanical properties of food materials [12-13]. Image texture is defined as the spatial organization of intensity variations of pixels in gray level image, which corresponded to both brightness value and pixel locations [14]. Image texture features are usually classified into four categories namely, statistical, structural, model-based and transform-based textures [15]. In the food systems, statistical texture is the most commonly used method for quality evaluations. This method includes Grey Level Co-Occurrence Matrix (GLCM), grey level pixel-run length matrix, and neighboring grey level dependence matrix [9]. The former that has been proposed by Haralick et al. [16], is the widely applied statistical texture analysis method, in which texture features such as entropy, homogeneity, correlation and contrast are extracted by some statistical approaches from the cooccurrence matrix of gray scale image histogram. GLCM has been used for classification of cereal grain and dockage [17], and apple [18].

There is not published data in the literature on mechanical and image texture properties of bread. Therefore, the objectives of the present work were to investigate the effect of different emulsifiers, concentrations and proofing times on bread quality factors and to study the efficiency of image texture analysis for prediction of mechanical texture property.

\section{Materials and Methods}

\section{Materials}

Commercial wheat flour (Golmakan Co., Khorasan Razavi, Iran), dry active yeast (Razavi Co., Khorasan, Iran) and emulsifiers (Sodium Stearoyl Lactylate (SSL), Diacetyl Tartaric Acid Ester of Monoglyceride (DATEM) and Mono-and diglycerides of fatty acids (E471)) (Pars Behbod Asia Co, Tehran, Iran) were bought from authoritative company. Other ingredients were purchased from local supermarket.

*Corresponding author: Milad Fathi, Department of Food Science and Technology, Isfahan University of Technology (IUT), Isfahan, 84156-83111, Iran, Tel: +98 311 3913368; Fax: +98 311 3913381; E-mail: milad fathi@stu-mail.um.ac.ir

Received September 12, 2012; Accepted October 15, 2012; Published October 25, 2012

Citation: Karimi M, Fathi M, Sheykholeslam Z, Sahraiyan B, Naghipoor F (2012) Effect of Different Processing Parameters on Quality Factors and Image Texture Features of Bread. J Bioprocess Biotech 2:127 doi: 10.4172/2155-9821.1000127

Copyright: ( 2012 Karimi M, et al. This is an open-access article distributed unde the terms of the Creative Commons Attribution License, which permits unrestricted use, distribution, and reproduction in any medium, provided the original author and source are credited. 
Citation: Karimi M, Fathi M, Sheykholeslam Z, Sahraiyan B, Naghipoor F (2012) Effect of Different Processing Parameters on Quality Factors and Image Texture Features of Bread. J Bioprocess Biotech 2:127 doi: 10.4172/2155-9821.1000127

Page 2 of 7

\section{Methods}

The bread formula consisted of flour (100 parts); water (50 parts), active dried yeast (1 part); salt (1 part); sugar (1 part); shortening (1 part) and emulsifier (0.2, 0.4 and $0.6 \%$ of applied flour). The baking procedure was followed based on typical methods [19]. Three different proofing times $(25,35$ and $45 \mathrm{~min})$ were considered at $45^{\circ} \mathrm{C}$. Baking was carried out using a laboratory air impingement oven (Minicombo rotor oven, Zucchelli, Italy) at $240^{\circ} \mathrm{C}$ for $10 \mathrm{~min}$. After cooling, bread samples were packed in polyethylene bags of $20 \mu \mathrm{m}$ thickness, stored at room temperature until future analysis.

Chemical analysis: Moisture (44-16 A), ash (08-07), dry gluten (38-12.02) and falling number (56-81) were determined according to AACC-approved methods [20]. Flour protein was assessed based on Kjeldahl using a Kjeltec auto protein tester (model 1030, Tecator Co., Hoeganaes, Sweden).

Specific volume: Specific volume was determined an hour after baking based on rapeseed displacement method [21-22].

Mechanical texture analysis: The hardness of bread samples was measured with a Texture Analyzer (CNS Farnell, Hertfordshire, UK) equipped with a $50 \mathrm{~N}$ load cell. A cylindrical probe with a diameter of $20 \mathrm{~mm}$ and height of $23 \mathrm{~mm}$ with the speed of $30 \mathrm{~mm} / \mathrm{min}$ was used for cubic samples with dimensions of $25 \times 25 \times 25$. The mechanical texture analysis of bread samples were performed after one day of production at room temperature based on the method of AACC [23].

Sensory analysis: The sensory analysis was conducted with a group of 10 semi-trained panelists, applying a hedonic scale of 5 point. Panelists were asked to assess the bread's quality factors including crumb color, crust color, taste, aroma, staling and total acceptance, to rate samples from 0 to 5 ( 0 unacceptable, 5 very acceptable).

Image analysis: For each treatment, three samples (crust and crumb) were scanned with desktop flatbed scanner (HP, Scanjet G3010; at Optical Resolution of $4800 \mathrm{dpi} \times 9600 \mathrm{dpi}$ ) and the images were saved as BMP format. To study the effect of processing parameters on color components of bread, the RGB color space images were converted to $L^{\star} a^{\star} b$ space [24]. For determination of the bread porosity using image analysis, the color images were first grayscaled and then thresholded using isodata algorithm. The porosity was measured from the ratio of white to the total numbers of pixels.

Grey level co-occurrence matrix and image texture analysis: The first procedure for extracting image textural features was presented by Haralick et al. [16]. Each textural property is computed from a set of GLCM probability distribution matrices for a given image. The GLCM shows the probability that a pixel of a particular grey level occurs at a specified direction and distance from its neighboring pixels. Gray level co-occurrence matrix is represented by $\mathrm{P}_{d, \theta(i, j)}$ where counts the neighboring pair pixels with gray values $i$ and $j$ at the distance of $d$ and the direction of $\theta$.

In this study, four image texture features namely, contrast, correlation, entropy and homogeneity were calculated based on equations 1-4 [12]. Contrast measures the local variation in an image (ranging from 0 to $[\text { size }(\mathrm{GLCM}, 1)-1]^{2}$ ) and a high contrast value indicates a high degree of local variation. Correlation is an indicator of linear dependency of intensity values in an image (ranging from -1 to 1 ). For an image with large areas of similar intensities, a high value of correlation is measured. Energy (angular second moment) returns the sum of squared elements in the GLCM (ranging from 0 to 1 ) and homogeneity indicates the uniformity within an image (ranging from 0 to 1 ).

$$
\begin{aligned}
& \text { Contrast }=\sum_{i=0}^{N-1} \sum_{j=0}^{N-1}(i-j)^{2} P_{d, \theta}(i, j) \\
& \text { Correlation }=\frac{\left[\sum_{i=0}^{N-1} \sum_{j=0}^{N-1}(i j) P_{d, \theta}(i, j)\right]-\mu_{x} \mu_{y}}{\sigma_{x} \sigma_{y}} \\
& \text { Energy }=\sum_{i=0}^{N-1} \sum_{j=0}^{N-1} P_{d, \theta}(i, j)^{2} \\
& \text { Homogeneity }=\sum_{i=0}^{N-1} \sum_{j=0}^{N-1} \frac{P_{d, \theta}(i, j)}{1+|i-j|}
\end{aligned}
$$

\begin{tabular}{|c|c|}
\hline Property & value \\
\hline Moisture $(\mathrm{g} / 100 \mathrm{~g}, \mathrm{w} . \mathrm{b})$. & $13.8 \pm 0.45$ \\
\hline Protein $(\mathrm{g} / 100 \mathrm{~g})$ & $10.8 \pm 0.60$ \\
\hline Ash $(\mathrm{g} / 100 \mathrm{~g})$ & $0.86 \pm 0.08$ \\
\hline Dry gluten $(\mathrm{g} / 100 \mathrm{~g})$ & $8.7 \pm 0.43$ \\
\hline Falling number $(\mathrm{s})$ & $423 \pm 1.83$ \\
\hline
\end{tabular}

Table 1: Quality characteristic of wheat flour and dough.

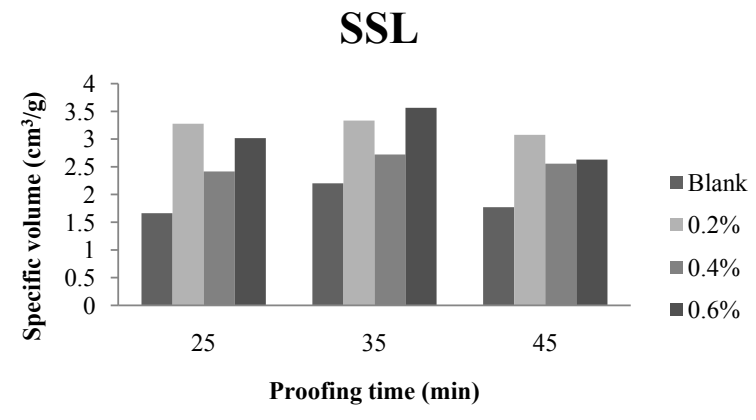

DATEM

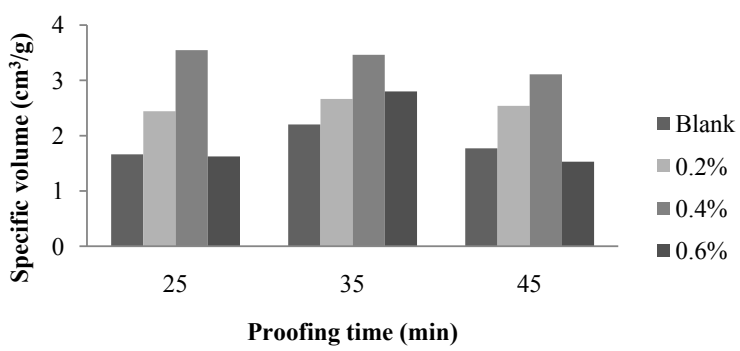

E471

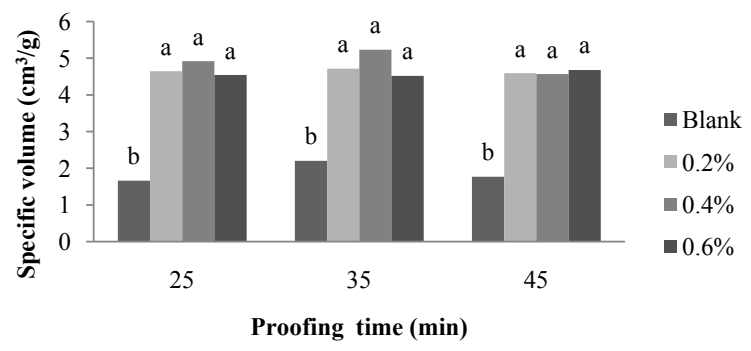

Figure 1: Specific volume of blank and emulsifier treated samples at different concentrations and proofing times (column with different letters are statistically significant). 
Citation: Karimi M, Fathi M, Sheykholeslam Z, Sahraiyan B, Naghipoor F (2012) Effect of Different Processing Parameters on Quality Factors and Image Texture Features of Bread. J Bioprocess Biotech 2:127 doi: 10.4172/2155-9821.1000127

Page 3 of 7

\begin{tabular}{|c|c|c|c|c|c|c|c|c|}
\hline \multirow{2}{*}{ Emulsifier } & \multirow{2}{*}{ Concentration (\%) } & \multirow{2}{*}{ Proofing time (min) } & \multicolumn{6}{|c|}{ Sensory properties } \\
\hline & & & Total acceptance & Crumb color & Taste & Crust color & Aroma & Staling \\
\hline \multirow[t]{3}{*}{ Blank } & 0 & 25 & $2.7 \pm 0.67^{\circ}$ & $2.5 \pm 0.84^{c}$ & $2.2 \pm 0.66^{c}$ & $2.7 \pm 0.67^{b}$ & $2.1 \pm 0.73^{c}$ & $1.8 \pm 0.63^{b}$ \\
\hline & 0 & 35 & $3 \pm 0.66^{c}$ & $2.7 \pm 0.67^{c}$ & $2.5 \pm 0.66^{c}$ & $2.5 \pm 0.66^{b}$ & $2.4 \pm 0.63^{c}$ & $2.1 \pm 0.73^{b}$ \\
\hline & 0 & 45 & $2.8 \pm 0.63^{c}$ & $2.7 \pm 0.67^{\circ}$ & $2.5 \pm 0.66^{c}$ & $2.4 \pm 0.62^{b}$ & $2.4 \pm 0.63^{c}$ & $2.2 \pm 0.66^{b}$ \\
\hline \multirow[t]{9}{*}{ E471 } & 0.2 & 25 & $3.6 \pm 0.51^{\mathrm{b}}$ & $3.4 \pm 0.96^{b}$ & $3.4 \pm 0.84^{b}$ & $3.5 \pm 0.52^{\mathrm{a}}$ & $2.9 \pm 0.73^{b}$ & $2.8 \pm 0.63^{\mathrm{ab}}$ \\
\hline & 0.2 & 35 & $3.9 \pm 0.56^{\mathrm{b}}$ & $3.4 \pm 0.73^{b}$ & $3.6 \pm 0.51^{\mathrm{b}}$ & $3.2 \pm 1.13^{\mathrm{a}}$ & $3 \pm 0.66^{b}$ & $3.1 \pm 0.73^{\mathrm{ab}}$ \\
\hline & 0.2 & 45 & $3.6 \pm 0.82^{b}$ & $3.4 \pm 0.84^{b}$ & $3.7 \pm 0.82^{b}$ & $3.2 \pm 0.66^{\mathrm{a}}$ & $3 \pm 0.63^{b}$ & $3.2 \pm 0.81^{\mathrm{ab}}$ \\
\hline & 0.4 & 25 & $3.6 \pm 0.51^{b}$ & $3.4 \pm 0.82^{b}$ & $3.7 \pm 0.82^{b}$ & $3.3 \pm 0.82^{\mathrm{a}}$ & $3 \pm 0.66^{b}$ & $2.9 \pm 0.73^{\mathrm{ab}}$ \\
\hline & 0.4 & 35 & $4 \pm 0.47^{\mathrm{ab}}$ & $3.7 \pm 0.82^{\mathrm{ab}}$ & $3.8 \pm 0.42^{\mathrm{ab}}$ & $3.3 \pm 0.82^{\mathrm{a}}$ & $3 \pm 0.66^{b}$ & $3.2 \pm 0.66^{\mathrm{ab}}$ \\
\hline & 0.4 & 45 & $3.5 \pm 0.52^{b}$ & $3.6 \pm 0.61^{\mathrm{ab}}$ & $3.6 \pm 0.84^{b}$ & $3.3 \pm 0.94^{\mathrm{a}}$ & $3.1 \pm 0.73^{b}$ & $3.5 \pm 0.84^{\mathrm{a}}$ \\
\hline & 0.6 & 25 & $3.5 \pm 0.52^{b}$ & $3.3 \pm 0.64^{b}$ & $2.9 \pm 0.74^{\mathrm{bc}}$ & $3.2 \pm 0.91^{a}$ & $3 \pm 0.66^{b}$ & $3.2 \pm 0.91^{\mathrm{ab}}$ \\
\hline & 0.6 & 35 & $3.9 \pm 0.74^{b}$ & $3.7 \pm 0.82^{\mathrm{ab}}$ & $3.5 \pm 0.70^{\mathrm{b}}$ & $3.3 \pm 0.78^{a}$ & $3.1 \pm 0.73^{b}$ & $3.1 \pm 0.83^{\mathrm{ab}}$ \\
\hline & 0.6 & 45 & $3.9 \pm 0.73^{b}$ & $3.5 \pm 0.70^{\mathrm{ab}}$ & $3.3 \pm 0.95^{b}$ & $3.3 \pm 0.82^{\mathrm{a}}$ & $3 \pm 0.66^{b}$ & $3.1 \pm 0.74^{\mathrm{ab}}$ \\
\hline \multirow[t]{9}{*}{ DATEM } & 0.2 & 25 & $3.2 \pm 0.91^{\mathrm{bc}}$ & $3.2 \pm 0.91^{b}$ & $3.2 \pm 0.91^{\mathrm{b}}$ & $3.5 \pm 0.70^{\mathrm{a}}$ & $2.7 \pm 0.67^{\mathrm{bc}}$ & $2.8 \pm 0.63^{\mathrm{ab}}$ \\
\hline & 0.2 & 35 & $3.7 \pm 0.94^{\mathrm{b}}$ & $3.1 \pm 0.73^{b}$ & $3.6 \pm 0.51^{b}$ & $3.2 \pm 0.91^{a}$ & $2.7 \pm 0.67^{\mathrm{bc}}$ & $3.4 \pm 0.95^{\mathrm{ab}}$ \\
\hline & 0.2 & 45 & $3.4 \pm 0.84^{\mathrm{b}}$ & $3 \pm 0.84^{b}$ & $3.3 \pm 0.82^{b}$ & $3 \pm 0.84^{a}$ & $2.6 \pm 0.69^{\mathrm{bc}}$ & $3.1 \pm 0.73^{\mathrm{ab}}$ \\
\hline & 0.4 & 25 & $3.4 \pm 0.84^{b}$ & $3.2 \pm 0.75^{b}$ & $3.5 \pm 0.52^{b}$ & $3.1 \pm 0.73^{\mathrm{a}}$ & $2.8 \pm 0.63^{b}$ & $2.9 \pm 0.73^{\text {ab }}$ \\
\hline & 0.4 & 35 & $3.8 \pm 0.78^{b}$ & $3.5 \pm 0.70^{\mathrm{ab}}$ & $3.6 \pm 0.69^{b}$ & $3.1 \pm 0.87^{\mathrm{a}}$ & $2.9 \pm 0.87^{b}$ & $3.2 \pm 0.91^{\mathrm{ab}}$ \\
\hline & 0.4 & 45 & $3.3 \pm 0.94^{b}$ & $3.4 \pm 0.84^{b}$ & $3.4 \pm 0.84^{b}$ & $3 \pm 0.66^{a}$ & $2.9 \pm 0.73^{b}$ & $3 \pm 0.66^{\mathrm{ab}}$ \\
\hline & 0.6 & 25 & $3.1 \pm 0.73^{b c}$ & $3 \pm 0.47^{b}$ & $2.6 \pm 0.84^{c}$ & $2.9 \pm 0.73^{a}$ & $2.6 \pm 0.69^{\mathrm{bc}}$ & $2.9 \pm 0.73^{\mathrm{ab}}$ \\
\hline & 0.6 & 35 & $3.7 \pm 0.94^{b}$ & $3.4 \pm 0.86^{b}$ & $3.2 \pm 0.91^{\mathrm{b}}$ & $3 \pm 0.66^{\mathrm{a}}$ & $2.8 \pm 0.63^{b}$ & $3.1 \pm 0.73^{\mathrm{ab}}$ \\
\hline & 0.6 & 45 & $3.3 \pm 0.94^{\mathrm{b}}$ & $3.2 \pm 0.91^{\mathrm{b}}$ & $3 \pm 0.66^{b}$ & $3 \pm 0.0^{\mathrm{a}}$ & $2.7 \pm 0.67^{\mathrm{bc}}$ & $3.1 \pm 0.56^{\mathrm{ab}}$ \\
\hline \multirow[t]{9}{*}{ SSL } & 0.2 & 25 & $3.7 \pm 0.82^{b}$ & $3.5 \pm 0.52^{\mathrm{ab}}$ & $3.6 \pm 0.84^{b}$ & $3.6 \pm 0.51^{\mathrm{a}}$ & $3.1 \pm 0.87^{b}$ & $3.4 \pm 0.96^{\mathrm{ab}}$ \\
\hline & 0.2 & 35 & $4.1 \pm 0.87^{\mathrm{ab}}$ & $3.8 \pm 0.63^{a}$ & $3.9 \pm 0.56^{\mathrm{ab}}$ & $3.4 \pm 0.64^{\mathrm{a}}$ & $3.1 \pm 0.73^{b}$ & $3.4 \pm 0.69^{\mathrm{ab}}$ \\
\hline & 0.2 & 45 & $3.7 \pm 0.67^{b}$ & $3.7 \pm 0.67^{\mathrm{ab}}$ & $3.5 \pm 0.52^{b}$ & $3.4 \pm 0.84^{\mathrm{a}}$ & $3.1 \pm 0.73^{b}$ & $3.2 \pm 0.78^{\mathrm{ab}}$ \\
\hline & 0.4 & 25 & $3.7 \pm 0.67^{\mathrm{b}}$ & $3.6 \pm 0.51^{\mathrm{ab}}$ & $3.6 \pm 0.96^{b}$ & $3.7 \pm 0.67^{\mathrm{a}}$ & $3.5 \pm 0.52^{\mathrm{a}}$ & $3.2 \pm 0.91^{\mathrm{ab}}$ \\
\hline & 0.4 & 35 & $4.3 \pm 0.48^{\mathrm{a}}$ & $4 \pm 0.47^{\mathrm{a}}$ & $4.3 \pm 0.48^{\mathrm{a}}$ & $3.7 \pm 0.82^{\mathrm{a}}$ & $3.8 \pm 0.91^{\mathrm{a}}$ & $3.5 \pm 0.70^{\mathrm{a}}$ \\
\hline & 0.4 & 45 & $3.9 \pm 0.87^{\mathrm{b}}$ & $3.9 \pm 0.87^{\mathrm{a}}$ & $4.1 \pm 0.56^{\mathrm{a}}$ & $3.4 \pm 0.84^{\mathrm{a}}$ & $3.7 \pm 0.82^{\mathrm{a}}$ & $3.3 \pm 0.82^{\mathrm{ab}}$ \\
\hline & 0.6 & 25 & $3.4 \pm 0.84^{\mathrm{b}}$ & $3.5 \pm 0.70^{\mathrm{ab}}$ & $3.5 \pm 0.70^{b}$ & $3.6 \pm 0.96^{a}$ & $3.4 \pm 0.69^{b}$ & $3.2 \pm 0.91^{\mathrm{ab}}$ \\
\hline & 0.6 & 35 & $3.6 \pm 0.51^{\mathrm{b}}$ & $3.8 \pm 0.78^{\mathrm{a}}$ & $4.2 \pm 0.63^{\mathrm{a}}$ & $3.7 \pm 0.94^{\mathrm{a}}$ & $3.7 \pm 0.82^{\mathrm{a}}$ & $3.6 \pm 0.84^{a}$ \\
\hline & 0.6 & 45 & $3.1 \pm 0.56^{\mathrm{bc}}$ & $3.7 \pm 0.82^{\mathrm{ab}}$ & $4.1 \pm 0.56^{a}$ & $3.3 \pm 0.82^{\mathrm{a}}$ & $3.5 \pm 0.52^{b}$ & $3.4 \pm 0.84^{\mathrm{ab}}$ \\
\hline
\end{tabular}

Values in each column with different letters are statistically significant $(p<0.05)$.

Table 2: Sensory properties of blank and emulsifier treated bread.

\begin{tabular}{|c|c|c|c|c|c|c|}
\hline Emulsifier & Concentration (\%) & Proofing time (min) & $L^{*}$ & $a^{* N S}$ & $b^{* N S}$ & Porosity (\%) \\
\hline \multirow[t]{3}{*}{ Blank } & 0 & 25 & $54.45^{d}$ & 11.98 & 39.2 & $20.7^{\mathrm{h}}$ \\
\hline & 0 & 35 & $56.82^{\mathrm{dc}}$ & 15.28 & 46.26 & $23.5^{\mathrm{gh}}$ \\
\hline & 0 & 45 & $59.64^{\text {bc }}$ & 12.45 & 40.75 & $25.1^{9}$ \\
\hline \multirow[t]{9}{*}{ E471 } & 0.2 & 25 & $69.76^{a}$ & 6.94 & 41.49 & $31.0^{f}$ \\
\hline & 0.2 & 35 & $65.23^{\mathrm{ab}}$ & 9.86 & 44.56 & $31.3^{f}$ \\
\hline & 0.2 & 45 & $67.35^{\mathrm{a}}$ & 9.85 & 46.23 & $32.2^{f}$ \\
\hline & 0.4 & 25 & $62.65^{b}$ & 10.46 & 41.7 & $32.5^{f}$ \\
\hline & 0.4 & 35 & $61.86^{b}$ & 10.92 & 41.1 & $33.5^{\text {ef }}$ \\
\hline & 0.4 & 45 & $60.54^{b}$ & 12.47 & 40.73 & $33.8^{\mathrm{ef}}$ \\
\hline & 0.6 & 25 & $55.19^{d c}$ & 14.4 & 39.78 & $33.5^{\text {ef }}$ \\
\hline & 0.6 & 35 & $62.19^{b}$ & 13.13 & 62.19 & $33.7^{\text {ef }}$ \\
\hline & 0.6 & 45 & $56.21^{d c}$ & 14.42 & 14.3 & $35.4^{\mathrm{de}}$ \\
\hline \multirow[t]{9}{*}{ DATEM } & 0.2 & 25 & $53.68^{d}$ & 10.45 & 45.82 & $31.3^{f}$ \\
\hline & 0.2 & 35 & $62.15^{b}$ & 14.46 & 44.76 & $35.9^{\mathrm{e}}$ \\
\hline & 0.2 & 45 & $61.12^{\mathrm{b}}$ & 13.83 & 42.65 & $37.4^{\mathrm{d}}$ \\
\hline & 0.4 & 25 & $65.72^{\mathrm{ab}}$ & 13.59 & 48.9 & $34.4^{\mathrm{e}}$ \\
\hline & 0.4 & 35 & $65.95^{\mathrm{ab}}$ & 12.05 & 65.95 & $36.8^{\text {de }}$ \\
\hline & 0.4 & 45 & $62.19^{b}$ & 13.13 & 62.19 & $37.1^{d}$ \\
\hline & 0.6 & 25 & $65.4^{\mathrm{ab}}$ & 11.1 & 43.86 & $38.3^{d}$ \\
\hline & 0.6 & 35 & $64.55^{\mathrm{ab}}$ & 14.4 & 47.76 & $38.8^{d}$ \\
\hline & 0.6 & 45 & $62.41^{b}$ & 14.65 & 46.94 & $38.3^{d}$ \\
\hline \multirow[t]{9}{*}{ SSL } & 0.2 & 25 & $67.35^{a}$ & 9.85 & 46.23 & $40.0^{c}$ \\
\hline & 0.2 & 35 & $56.21^{c}$ & 14.42 & 44.3 & $40.3^{c}$ \\
\hline & 0.2 & 45 & $63.01^{b}$ & 13.53 & 45.95 & $42.2^{b}$ \\
\hline & 0.4 & 25 & $59.5^{\mathrm{bc}}$ & 15.7 & 51.04 & $40.5^{c}$ \\
\hline & 0.4 & 35 & $62.73^{b}$ & 9.72 & 44.35 & $41.5^{\mathrm{b}}$ \\
\hline & 0.4 & 45 & $61.27^{\mathrm{b}}$ & 10.75 & 43.95 & $42.1^{\mathrm{b}}$ \\
\hline & 0.6 & 25 & $60.73^{b}$ & 13.74 & 43.33 & $41.5^{\mathrm{b}}$ \\
\hline & 0.6 & 35 & $69.9^{a}$ & 9.99 & 42.79 & $42.7^{b}$ \\
\hline & 0.6 & 45 & $63.21^{b}$ & 9.12 & 42.92 & $43.4^{a}$ \\
\hline
\end{tabular}

Values in each column with different letters are statistically significant $(p<0.05)$; Ns, not statistically significant.

Table 3: Image color properties and porosity values extracted from bread image. 
where $\mu_{x}, \mu_{y}$ and $\sigma_{x}, \sigma_{y}$ are the mean and standard deviation of the sums of rows and columns in the matrix, respectively, and $\mathrm{N}$ is the dimension of square matrix of GLCM. In this study, the four mentioned textural features were computed using the mean of the four values of different orientations $\left(0^{\circ}, 45^{\circ}, 90^{\circ}\right.$ and $\left.135^{\circ}\right)$ at $\mathrm{d}=1$ applying a program developed in MATLAB 7.0.

Statistical analysis: Analysis of variance (ANOVA) was performed using a computerized statistical program called "MSTAT" version C, and determination of significant differences of means was carried out by "Duncan" test at 95\% confidence level applying the above software program. Regression equations and correlation coefficients (R) between the mechanical and image texture features were obtained using Minitab software, version 14. Each experiment was conducted applying factorial design at least in three replications.

\section{Results and Discussions}

In this study, 27 different bread samples were formulated using three emulsifiers in three concentrations at three proofing times. The physicochemical compositions of wheat and dough are tabulated in Table 1. These characteristics in the range of typical values of medium strong flour.

The results indicated that application of E471 in bread formulation
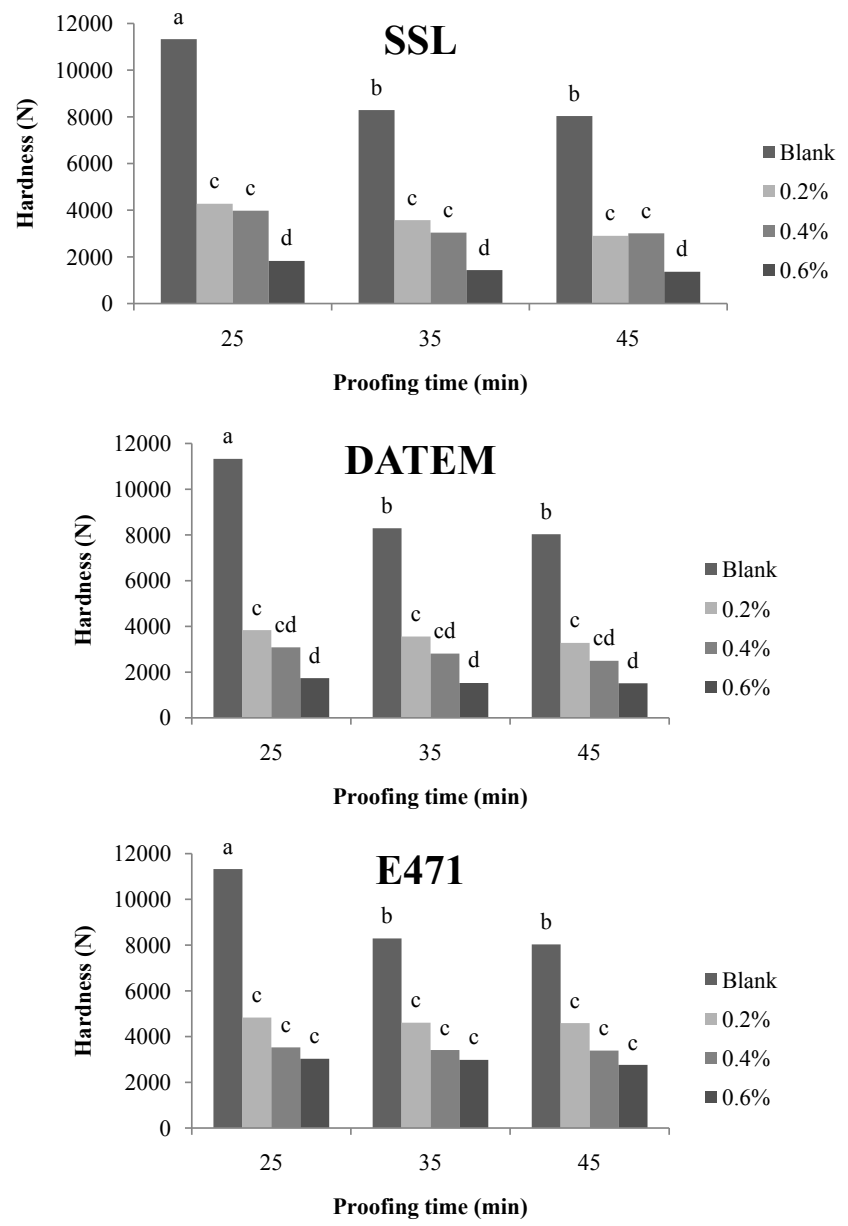

Figure 2: Hardness of blank and emulsifier treated samples at differen concentrations and proofing times (column with different letters are statistically significant). led to a significant increase $(\mathrm{p}<0.05)$ in specific volume (Figure 1$)$. It may be attributed to ability of emulsifier to permit dough expansion during baking process. However, the effects of proofing time, SSL and DATEM were not statistically significant. Ribotta et al. [25] reported that emulsifier treated bread had the higher specific volume in comparison to control samples.

Table 2 indicates the sensory attributes of blank and emulsifier treated samples which were evaluated a day after baking. As one can see, emulsifier addition has significant influences on all sensory properties (test, aroma, crumb color, crust color and staling and total acceptance). Taste and aroma are two important quality characteristics in food acceptance, which are difficult to determine by instrumental measurements. Taste and aroma of emulsifier treated breads gained higher scores in comparison to blank samples. The crumb and crust colors were enhanced by using emulsifiers. The staling results indicated that the applied emulsifiers could delay, about two times, the retrogradation process. Among different emulsifiers, SSL showed better sensory attributes. In most cases, the proofing time did not show significant effect on sensory properties. The calculated averages of all quality scores of treated samples were higher than control breads; therefore, sensory analysis allows concluding that addition of emulsifiers improves sensory properties of fresh bread.

The average values of $L^{*}, a^{*}, b^{*}$ and porosity extracted from bread images tabulated in table 3 . The results indicated that the effects of treatments were not statistically significant on color components of $a^{*}$ and $b^{*}$. However, lightness $\left(L^{*}\right)$ of bread increased by emulsifier addition, which could be attributed to the positive effect of emulsifiers to enhance lightness of bakery products. The porosity of bread enhanced by emulsifier addition and increasing emulsifier concentration and proofing time. It may be the consequence of higher incorporation of air into dough with increasing proofing time and high ability of emulsifieramylose complex to retain the gas.

The effect of process variables on hardness of bread was depicted in Figure 2. All applied emulsifiers showed significant effect $(\mathrm{p}<0.05)$ on hardness. By increasing emulsifier concentration and proofing time the hardness of bread diminished. However, the effect of SSL pronounced more strongly, which caused about five times decrease in hardness of bread. It could be due to interaction of amylose and emulsifiers which led to retardation of retrogradation and decrease of hardness [1]. On the other hand, increasing proofing time caused an increase in $\mathrm{CO}_{2}$ production, raising porosity and consequently decreasing of hardness.

Aforementioned statements indicate that determination of mechanical texture properties of food products is both destructive and time-consuming. Four image texture features (i.e. contrast, correlation, energy and homogeneity) of bread were calculated from GLCM in four orientations at the distance of one pixel and their average values for different emulsifiers, concentrations and proofing times were shown in Table 4. The contrast decreased in results of emulsifier addition due to diminish of local variation of pixels. The softer the texture the lower the contrast, which is due to lower pixel value difference between two neighbors [14]. On the other hand, the increasing trends of energy, correlation and homogeneity values revealed improvement of uniformity and smoothness of the images due to decrease of coalescence and increase of softness of bread texture. Similar trends were also reported by Qiao et al [12] for image textural properties of nugget. In this research an effort has been made to apply image texture analysis as a nondestructive and rapid method to predict mechanical properties of bread. To evaluate the capability of image texture features 
Citation: Karimi M, Fathi M, Sheykholeslam Z, Sahraiyan B, Naghipoor F (2012) Effect of Different Processing Parameters on Quality Factors and Image Texture Features of Bread. J Bioprocess Biotech 2:127 doi: 10.4172/2155-9821.1000127

Page 5 of 7

\begin{tabular}{|c|c|c|c|c|c|c|}
\hline \multirow{2}{*}{ Emulsifier } & \multirow{2}{*}{ Concentration (\%) } & \multirow{2}{*}{ Proofing time $(\mathrm{min})$} & \multicolumn{4}{|c|}{ Image texture feature } \\
\hline & & & Contrast & Correlation & Energy & Homogeneity \\
\hline \multirow[t]{3}{*}{ Blank } & 0 & 25 & $0.360175^{a}$ & $0.7651^{\mathrm{e}}$ & $0.17215^{\mathrm{e}}$ & $0.746075^{f}$ \\
\hline & 0 & 35 & $0.289825^{\mathrm{b}}$ & $0.8242^{d}$ & $0.249075^{\mathrm{d}}$ & $0.763025^{\mathrm{e}}$ \\
\hline & 0 & 45 & $0.288575^{\mathrm{b}}$ & $0.825275^{d}$ & $0.24584^{d}$ & $0.7769^{d}$ \\
\hline \multirow[t]{9}{*}{ SSL } & 0.2 & 25 & $0.210925^{c}$ & $0.884175^{c}$ & $0.29993^{c}$ & $0.904575^{c}$ \\
\hline & 0.2 & 35 & $0.202225^{c}$ & $0.890925^{\text {bc }}$ & $0.31075^{c}$ & $0.908325^{c}$ \\
\hline & 0.2 & 45 & $0.20025^{c}$ & $0.89385^{\mathrm{bc}}$ & $0.325225^{\text {bc }}$ & $0.91649 b^{c}$ \\
\hline & 0.4 & 25 & $0.20265^{c}$ & $0.886175^{c}$ & $0.293775^{c}$ & $0.905^{c}$ \\
\hline & 0.4 & 35 & $0.200225^{c}$ & $0.893475^{\text {bc }}$ & $0.33335^{b}$ & $0.915525^{b c}$ \\
\hline & 0.4 & 45 & $0.200108^{c}$ & $0.89305^{\mathrm{bc}}$ & $0.320025^{\text {bc }}$ & $0.915075^{\text {bc }}$ \\
\hline & 0.6 & 25 & $0.15575^{d}$ & $0.9001^{\mathrm{b}}$ & $0.331125^{b}$ & $0.9235^{\mathrm{b}}$ \\
\hline & 0.6 & 35 & $0.1491 d^{e}$ & $0.91865^{a}$ & $0.339985^{a}$ & $0.929825^{a}$ \\
\hline & 0.6 & 45 & $0.145375^{e}$ & $0.91995^{\mathrm{a}}$ & $0.342225^{a}$ & $0.931958^{a}$ \\
\hline \multirow[t]{9}{*}{ DATEM } & 0.2 & 25 & $0.207325^{c}$ & $0.887^{c}$ & $0.298275^{c}$ & $0.904^{c}$ \\
\hline & 0.2 & 35 & $0.2023^{c}$ & $0.889025^{c}$ & $0.310925^{c}$ & $0.9094^{b c}$ \\
\hline & 0.2 & 45 & $0.2017^{c}$ & $0.892625^{c}$ & $0.31173^{c}$ & $0.909933^{b c}$ \\
\hline & 0.4 & 25 & $0.200725^{c}$ & $0.893075^{b c}$ & $0.314675^{c}$ & $0.9151^{\mathrm{bc}}$ \\
\hline & 0.4 & 35 & $0.200305^{c}$ & $0.8948^{\text {bc }}$ & $0.32585^{\mathrm{bc}}$ & $0.915775^{b c}$ \\
\hline & 0.4 & 45 & $0.199225^{\mathrm{cd}}$ & $0.8997^{b}$ & $0.32995^{b}$ & $0.91609^{b c}$ \\
\hline & 0.6 & 25 & $0.1669^{d}$ & $0.900025^{b}$ & $0.33245^{\mathrm{a}}$ & $0.9267^{b}$ \\
\hline & 0.6 & 35 & $0.149975^{\text {de }}$ & $0.91446^{a}$ & $0.33685^{\mathrm{a}}$ & $0.92905^{a}$ \\
\hline & 0.6 & 45 & $0.14903^{\mathrm{de}}$ & $0.914925^{a}$ & $0.33608^{a}$ & $0.929625^{a}$ \\
\hline \multirow[t]{9}{*}{ E471 } & 0.2 & 25 & $0.22021^{\mathrm{bc}}$ & $0.877546^{c}$ & $0.29486^{c}$ & $0.89393^{c}$ \\
\hline & 0.2 & 35 & $0.21593^{c}$ & $0.87678^{c}$ & $0.296767^{\circ}$ & $0.897543^{c}$ \\
\hline & 0.2 & 45 & $0.214^{c}$ & $0.877767^{c}$ & $0.297878^{c}$ & $0.899768^{c}$ \\
\hline & 0.4 & 25 & $0.20222^{c}$ & $0.889787^{b c}$ & $0.311233^{c}$ & $0.9094^{c}$ \\
\hline & 0.4 & 35 & $0.20121^{c}$ & $0.889967^{b c}$ & $0.311876^{c}$ & $0.909756^{c}$ \\
\hline & 0.4 & 45 & $0.201021^{c}$ & $0.890004^{\mathrm{bc}}$ & $0.311212^{c}$ & $0.9098^{\mathrm{bc}}$ \\
\hline & 0.6 & 25 & $0.20107^{c}$ & $0.89306^{\mathrm{bc}}$ & $0.32^{\mathrm{bc}}$ & $0.9154^{b c}$ \\
\hline & 0.6 & 35 & $0.20012^{c}$ & $0.89452^{\mathrm{bc}}$ & $0.32012^{\mathrm{bc}}$ & $0.9162^{b c}$ \\
\hline & 0.6 & 45 & $0.200001^{c}$ & $0.89676^{\text {bc }}$ & $0.32434^{\mathrm{bc}}$ & $0.9168^{b c}$ \\
\hline
\end{tabular}

Values in each column with different letters are statistically significant $(p<0.05)$

Table 4: Image texture features (contrast, correlation, energy and homogeneity) of blank and treated bread.

for estimation of hardness of bread, linear regressions were conducted between contrast, correlation, energy and homogeneity and hardness (Figure 3). The mathematical linear equations between image texture features and hardness and their correlation coefficients (Figure 3) indicated that all four image texture features showed excellent correlations with hardness $(0.958,0.973,0.966$ and 0.91 for contrast, correlation, energy and homogeneity, respectively). The Multiple Linear Regressions (MLR) between image texture features and hardness of bread (Eq. 5) showed the capability of image properties to predict a mechanical feature of bread $\left(R^{2}=0.994\right)$.

Hardness $=9654+21208[$ Contrast $]+9317[$ Correlation -31645$]$ [Energy] - 9816 [Homogeneity] $R^{2}=0.994$

The ANOVA results of MLR are shown in Table 5, indicate that the coefficients of regression equation are statistically significant. The above results reveal that image texture features can be strongly suggested as a nondestructive and rapid method for quality control of mechanical properties of bread.

\section{Conclusion}

The main aim of this work was to apply image texture analysis for prediction of a mechanical texture property of bread and the sub-aim was to investigate the effect of emulsifier and proofing time on some sensory and physical properties of bread. The following conclusions have been conducted for this research: i. E471 significantly increased $(\mathrm{p}<0.05)$ specific volume of bread. Whereas, DATEM, SSL, emulsifier concentration and proofing time did not had significant effect.

ii. All sensory properties including crumb color, crust color, test, aroma and staling and total acceptance positively and significantly affected by emulsifier addition. The effect of SSL pronounced more strongly. However, proofing time did not show significant effect on almost all sensory features.

iii. Lightness and porosity were calculated from crust and crumb images. Lightness increased by emulsifier addition and porosity also improved by increasing emulsifier concentration and proofing time.

iv. Hardness of bread decreased (up to five times) by increasing emulsifier concentration and proofing time.

v. Contrast, correlation, energy and homogeneity were calculated from GLCM. They showed high correlations with hardness of bread $(0.958,0.973,0.966$ and 0.91 , respectively). Multiple Linear Regression (MLR) between hardness and four image texture features could predict hardness with high correlation of coefficient of 0.994 .

The results of current research strongly suggest that applied emulsifiers could improve quality factors of bread and image texture 
Citation: Karimi M, Fathi M, Sheykholeslam Z, Sahraiyan B, Naghipoor F (2012) Effect of Different Processing Parameters on Quality Factors and Image Texture Features of Bread. J Bioprocess Biotech 2:127 doi: 10.4172/2155-9821.1000127
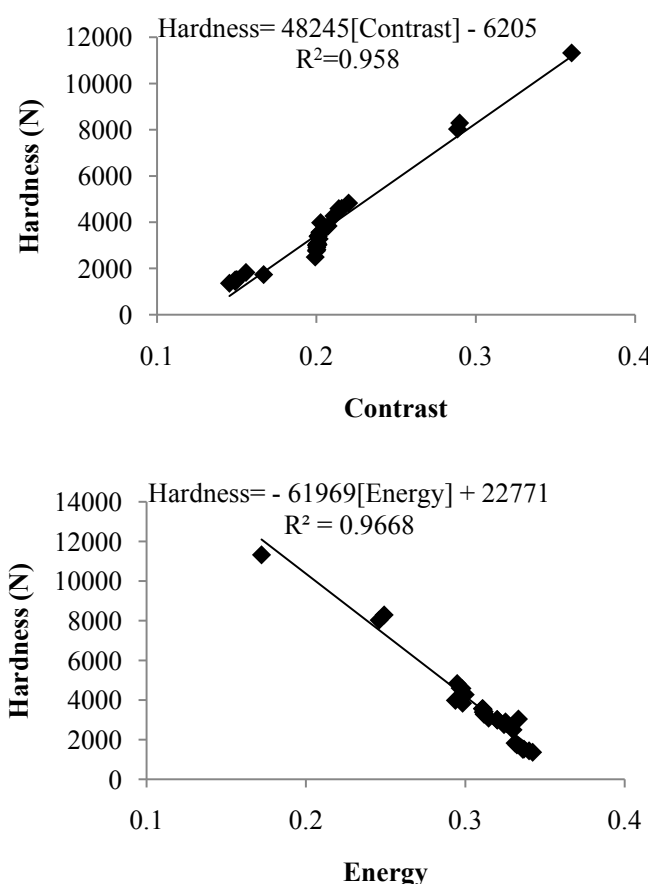
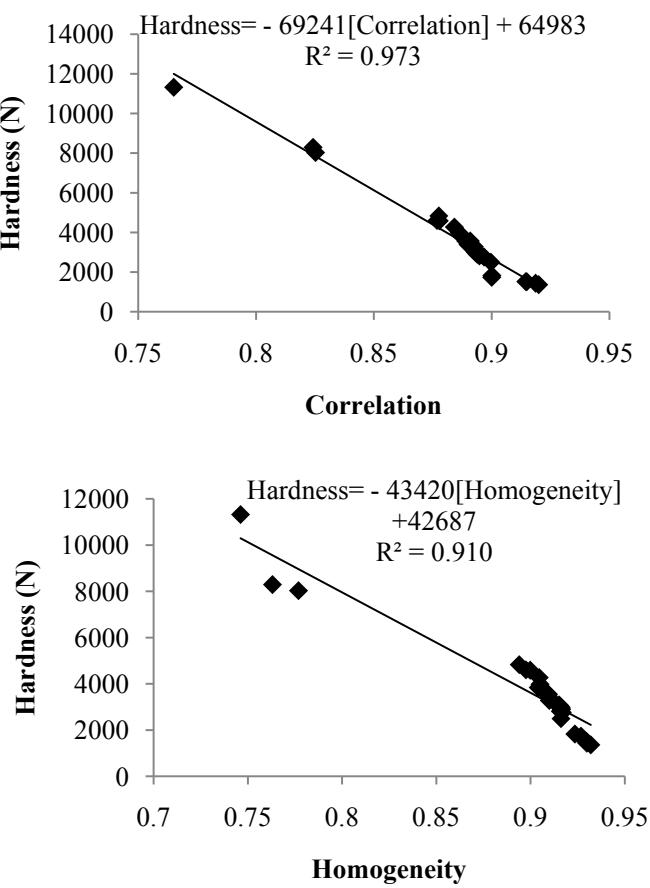

Figure 3: Correlation between hardness and image texture features.

\begin{tabular}{|c|c|c|c|c|}
\hline Source & DF & SS & MS & P \\
\hline Regression & 4 & 133933597 & 33483399 & 632.35 \\
\hline Residual error & 25 & 1323768 & 52951 & 0.00 \\
\hline Total & 29 & 135257365 & & \\
\hline
\end{tabular}

Table 5: The ANOVA results of multiple linear regressions between hardness and four image texture features.

analysis can be applied as a nondestructive rapid method for estimation of hardness of bread.

\section{References}

1. Azizi MH, Rao GV (2005) Effect of storage of surfactant gels on the bread making quality of wheat flour. Food Chem 89: 133-138.

2. Krog N, Jensen BN (1970) Interaction of monoglycerides in different physical states with amylose and their anti-firming effects in bread. Int $\mathrm{J}$ Food Sci Tech 5: 77-87.

3. Koocheki A, Mortazavi SA, Mahalati MN, Karimi M (2009) Effect of emulsifiers and fungal $\alpha$-amylase on rheological characteristics of wheat dough and quality of flat bread. J Food Process Eng 32: 187-205.

4. Nunes MHB, Moore MM, Ryan LAM, Arendt EK (2009) Impact of emulsifiers on the quality and rheological properties of gluten-free breads and batters. Eur Food Res Technol 228: 633-642.

5. Moayedallaie S, Mirzaei M, Paterson J (2010) Bread improvers: Comparison of a range of lipases with a traditional emulsifier. Food Chem 122: 495-499.

6. Chin NL, Tan LH, Yusof YA, Rahman RA (2009) Relationship between aeration and rheology of breads. J Texture Stud 40: 727-738.

7. Dan H, Azuma T, Kohyama K (2007) Characterization of spatiotempora stress distribution during food fracture by image texture analysis methods. $J$ Food Eng 81: 429-436.

8. Borah S, Hines EL, Bhuyan M (2007) Wavelet transform based image texture analysis for size estimation applied to the sorting of tea granules. J Food Eng 79: 629-639.

9. Zheng C, Sun DW, Zheng $L$ (2006) Recent applications of image texture for evaluation of food qualities-a review. Trends Food Sci Tech 17: 113-128.

10. Gonzales-Barron U, Butler F (2008) Discrimination of crumb grain visual appearance of organic and non-organic bread loaves by image texture analysis. J Food Eng 84: 480-488.

11. Fathi M, Mohebbi M, Razavi SMA (2009) Application of image texture analysis for evaluation of Osmotically Dehydrated Kiwifruit Qualities. 5th International Symposium on Food Rheology and Structure-Isfrs.

12. Qiao J, Wang N, Ngadi MO, Kazemi S (2007) Predicting mechanical properties of fried chicken nuggets using image processing and neura network techniques. J Food Eng 79: 1065-1070

13. Thybo AK, Szczypinski PM, Karlsson AH, Dønstrup S, Stodkilde-Jorgensen $\mathrm{HS}$, et al. (2004) Prediction of sensory texture quality attributes of cooked potatoes by NMR-imaging (MRI) of raw potatoes in combination with different image analysis methods. J Food Eng 61: 91-100.

14. Pietikanen MK (2000) Texture analysis in machin vision. World Scientific London.

15. Bharati MH, Liu JJ, MacGregor JF (2004) Image texture analysis: methods and comparisons. Chemometr Intell Lab 72: 57-71.

16. Haralick RM, Shanmugam K, Dinstein I (1973) Textural features for image classification. IEEE T Syst Man Cyb SMC3: 610-621.

17. Paliwal J, Visen NS, Jayas DS, White NDG (2003) Cereal Grain and Dockage Identification using Machine Vision. Biosyst Eng 85: 51-57.

18. Kavdir I, Guyer DE (2002) Apple sorting using artificial neural networks and spectral imaging. T ASAE 45: 1995-2005

19. Pourfarzad A, Khodaparast MHH, Karimi M, Mortazavi SA, Davoodi MG, et al. (2011) Effect of polyols on shelf-life and quality of flat bread fortified with soy flour. J Food Process Eng 34: 1435-1448

20. AACC (2000) Approved Methods of the AACC. Methods 44-16 A, 08-07 30-10, 38-11, 56-81. American Association of Cereal Chemists, St. Paul, $\mathrm{MN}$ 
Citation: Karimi M, Fathi M, Sheykholeslam Z, Sahraiyan B, Naghipoor F (2012) Effect of Different Processing Parameters on Quality Factors and Image Texture Features of Bread. J Bioprocess Biotech 2:127 doi: 10.4172/2155-9821.1000127

21. Sabanis D, Tzia C, Papadakis S (2008) Effect of Different Raisin Juice Preparations on Selected Properties of Gluten-Free Bread. Food Bioprocess Tech 1: 374-383

22. Barcenas ME, Rosell CM (2006) Different approaches for improving the quality and extending the shelf life of the partially baked bread: low temperatures and HPMC addition. J Food Eng 72: 92-99.

23. AACC (2004) Approved Methods of the AACC. Methods 10-05, 74-09. American Association of Cereal Chemists, St. Paul, MN.
24. Fathi M, Mohebbi M, Razavi SMA (2011) Application of Image Analysis and Artificial Neural Network to Predict Mass Transfer Kinetics and Color Changes of Osmotically Dehydrated Kiwifruit. Food Bioprocess Tech 4: 1357 1366 .

25. Ribotta PD, Pérez GT, Añón MC, León AE (2010) Optimization of Additive Combination for Improved Soy-Wheat Bread Quality. Food Bioprocess Tech 3: 395-405. 